\title{
Performances de gênero e raça no ativismo digital de Geledés: interseccionalidade, posicionamentos interacionais e reflexividade
}

\section{Gender and Race Performances in the Digital Activism of Geledés: Intersectionality, Interactional Positions and Reflectivity}

\author{
Danillo da Conceição Pereira Silva*,** \\ *Instituto Federal de Alagoas (IFAL), Santana do Ipanema, Alagoas / Brasil \\ **Universidade Federal de Sergipe (UFS), São Cristóvão, Sergipe/ Brasil. \\ danillosh@gmail.com \\ https://orcid.org/0000-0003-4704-1873
}

RESUMO: Considerando a crescente atuação dos ativismos digitais de
feminismos negros na sociedade brasileira, este artigo tem como objetivo analisar
performances de gênero e raça produzidas em posicionamentos interacionais
mobilizados por sujeitos em seus comentários na página do coletivo Geledés no
Facebook. Para tanto, foram adotadas perspectivas performativas de linguagem,
identidade, gênero e raça, bem como uma metodologia qualitativa inspirada
na etnografia virtual. Os resultados obtidos apontam para a intersecção entre
performances de gênero e raça nas práticas identitárias desempenhadas pelos(as)
comentadores(as), bem como para o potencial de reflexividade dessas práticas
sociais, especialmente no que tange à contestação de narrativas coloniais calcadas
no racismo e no sexismo.

PALAVRAS-CHAVE: ativismo digital; feminismo negro; performances identitárias; posicionamento interacional; interseccionalidade.

\begin{abstract}
Considering the increasing activity of digital activism of black feminism in Brazilian society, this article analyzes gender and racial performance produced in interactional positioning mobilized by subjects in their comments on the Geledés Facebook page. For that, performative perspectives of language, identity, gender and race were adopted, as well as a post-critical qualitative methodology inspired by virtual ethnography. The results obtained point to the intersection between gender and racial performances in identity-related practices performed by commentators, as well as to the reflexivity potential of these social practices, especially regarding the contestation of colonial narratives based on racism and sexism.
\end{abstract}

KEYWORKS: digital activism; black feminism; identity performance; interactional positioning; intersectionality. 


\section{Introdução}

$\mathrm{Na}$ modernidade recente (RAMPTON, 2006), marcada pela velocidade e pela fluidez dos fluxos informacionais, subjetivos, corporais e identitários, as redes digitais têm se tornado, dentre outras coisas, lugar privilegiado para a ampliação das possibilidades de participação e de mobilização social de grupos historicamente subalternizados. Como consequência desse relativo processo de democratização (BRAGA, 2010, 2015), parece ser uma característica dos modos de resistência do tempo presente a crescente apropriação de tecnologias e mídias digitais, por parte de tais grupos, com vistas a denunciar situações de violência e a reivindicar a efetivação de direitos humanos (MAIA, 2018). Assim, tornam-se notórias diferentes formas de engajamento político mediadas pelos recursos semióticos disponíveis nas diferentes plataformas e redes sociais digitais.

O fenômeno do ativismo digital, ou ciberativismo, a exemplo disso, tem se constituído como vetor de hibridização e de pulverização de performances identitárias, as quais produzem desestabilizações em uma matriz colonial, fundada historicamente sob a égide do racismo, do machismo, do sexismo, do ódio às dissidências sexuais e de gênero, por exemplo (MOITA LOPES, 2010; SILVA, 2019). É em relação a essa produção de corpos racializados que os ativismos digitais contemporâneos se constituem como espaços com alto potencial de reflexividade social (GIDDENS, 1991). Isso porque seus modos de agência põem em suspeição narrativas sociais cristalizadas e posições de sujeito tradicionalmente legitimadas.

Nesse contexto, os feminismos negros contemporâneos têm feito de sua presença em espaços digitais, especialmente nas redes sociais, importante instrumento de luta política e de formação cidadã, por meio da produção e da circulação de conteúdos de militância. Esse recurso amplia e diversifica suas possibilidades de intervenção social no embate histórico com vistas à superação das inúmeras violências às quais estão submetidas mulheres negras na sociedade brasileira, em face da particular intersecção entre forças de subordinação (CARNEIRO, 2003; CRENSHAW, 1989, 2002) potencialmente advindas tanto da projeção de marcadores sociais da diferença tanto relativas ao gênero quanto relativas à raça.

Tendo em vista esse contexto de intensa apropriação midiática por parte dos feminismos negros, este artigo tem como objetivos centrais: (1) contribuir, do ponto de vista teórico, com a ampliação das discussões sobre 
linguagem, gênero e raça, a partir do diálogo entre perspectivas performativas e interseccionais; e (2) do ponto de vista analítico, produzir interpretações contingentes acerca das performances de gênero e raça indexicalizadas nos posicionamentos interacionais (DAVIES; HARRÉ, 1990), projetados em comentários de sujeitos engajados em práticas de ativismo digital na página do coletivo Geledés no Facebook.

\section{Feminismos negros, interseccionalidade e ativismos digitais: $o$ Geledés no Facebook}

Nos ditames de um modelo de sociedade racista, em geral, corpos racializados como negros são esvaziados de sua condição de humanidade e de subjetividade, sofrendo um nefasto processo de objetificação (FANON, 2008) e tornando-se alvo de um intrincado espectro de violências. De modo particular, quando esse corpo racializado é reconhecido socialmente sob a categoria de gênero "mulher", essa dinâmica é ainda mais complexificada. Tal fato se deve à intersecção específica entre marcadores de subalternidade que posicionam mulheres negras sob o eixo central das necropolíticas (MBEMBE, 2018) em funcionamento na organização sociopolítica do Estado e da sociedade brasileiros. Em função disso, se instauram naturalizações acerca da confluência entre processos de exclusão estruturais motivados por fatores de raça, de gênero e também de classe, uma vez que a maior parte da população empobrecida é negra, e, nela, são as mulheres as mais empobrecidas. ${ }^{1}$

Diante de tal realidade social, o feminismo negro se insurge enquanto movimento social fundamental para a promoção de relações sociais mais equânimes e para a promoção de condições de subjetivação outras para as mulheres negras, a partir dos efeitos performativos de discursos antirracistas e anticoloniais. $\mathrm{Na}$ sua trajetória internacional enquanto movimento mais

\footnotetext{
${ }^{1}$ Segundo a pesquisa Mulheres e Trabalho, desenvolvida pelo Ministério do Trabalho, em parceria com o Instituto de Pesquisa Econômica Aplicada (Ipea), divulgada em 2016, $39,1 \%$ das mulheres negras estão inseridas em relações precárias de trabalho, seguidas pelos homens negros $(31,6 \%)$, pelas mulheres brancas $(27 \%)$ e pelos homens brancos $(20,6 \%)$ (IPEA, 2016). Tais indicadores, se assomados àqueles relativos aos índices de violências sofridas, de encarceramento, de acesso à saúde e à educação, bem como de renda per capita, facilmente sinalizam que é destinado à mulher negra o pior lugar na pirâmide social brasileira.
} 
institucionalizado, ${ }^{2}$ especificamente no contexto norte-americano, o feminismo negro surge em face da constatação de que as pautas levantadas pelo feminismo hegemônico, branco, não contemplavam as demandas específicas de mulheres negras, uma vez que reduziam "a mulher" a uma categoria essencializada, fixa e universalizante, projetando como sujeito de suas políticas uma mulher branca, heterossexual, escolarizada e de classe média, por exemplo. Nessa direção, feministas afro-americanas, como bell hooks, Patricia Hill Collins, Kimberlé Crenshaw e Audre Lorde, apontavam para a interseccionalidade como categoria analítica eficaz para se pensar os problemas das mulheres negras e como prática política de enfrentamento destes.

Nessa empreitada de um olhar que contemple a interseccionalidade (CRENSHAW, 1989, 2002), o desafio é não encarar os diversos marcadores como elementos que se somam, justapostos, na produção das experiências dos sujeitos, mas perceber como eles se atravessam de modo significativo, produzindo potencialmente condições específicas graças à sua interrelação. Nas palavras de Kimberlé Crenshaw (2002, p. 177), apesar de tal prática estar historicamente presente nas posições políticas do feminismo negro e de muitas mulheres negras, a interseccionalidade, enquanto instrumento teórico-analítico, diz respeito à "forma pela qual o racismo, o patriarcalismo, a opressão de classe e outros sistemas discriminatórios criam desigualdades básicas que estruturam as posições relativas de mulheres, raças, etnias, classes e outras". Ou seja, nos termos dos elementos problematizados neste artigo, caber-nos-ia pensar em termos de uma "racialização do gênero" ou da "generificação da raça", ou, ainda, em vez de focalizar a particularidade racial como mais uma opressão ladeada por outras, a exemplo da sexual ou de gênero, dimensionar as relações de constituição recíproca entre gênero e raça.

O prisma a partir do qual a interseccionalidade é tomada neste trabalho está sensivelmente afetado pelas tensões e provocações mútuas que o pensamento queer pode desencadear nesta poderosa estratégia analítica e teórica, a fim de complexificar os processos de produção de performances de gênero e de uma miríade rizomática de muitas outras diferenças. Assim,

\footnotetext{
${ }^{2}$ Faço essa ressalva com vistas a não invisibilizar uma miríade de processos de resistência e de lutas políticas encampadas por mulheres negras, em diferentes contextos e territórios, na experiência da diáspora africana, de modo mais ou menos institucionalizado.
} 
o pensamento de Jasbir Puar (2013) parece bastante profícuo nesse sentido, especialmente por destacar a possibilidade sempre aberta de não equivalência entre posição social empírica e posição de sujeito discursivamente produzida (ou de afetação cruzada de ambas, ao menos), bem como a inseparabilidade das condições de agenciamento, negociação, transgressão e resistência daquelas relativas à disciplina e ao controle das lógicas de subordinação, próprias do que é enfatizado no pensamento interseccional.

No que tange ao escopo brasileiro, as mulheres negras eram também invisibilizadas em suas pautas, tanto em razão da perspectiva homogeneizante que sobrepunha de modo isolado o marcador de gênero, a despeito de questões raciais, no movimento feminista tradicional brasileiro, quanto em função da desconsideração das especificidades de gênero experimentadas pelas mulheres negras no interior das práticas do movimento negro. Nesse âmbito, conforme discute Sueli Carneiro, em seu artigo "Enegrecer o feminismo" (2003), as mulheres negras organizadas impuseram suas perguntas críticas - especialmente interseccionais - tanto ao feminismo brasileiro hegemônico, particularmente brancocêntrico, quanto aos coletivos dos movimentos negros, particularmente masculinistas.

Nas palavras de Luiza Bairros (1995, p. 6), o feminismo negro diz respeito a "um conjunto de experiências e ideias compartilhadas por mulheres afro-americanas que oferecem um ângulo particular de visão do eu e da comunidade e da sociedade, que envolve interpretações teóricas da realidade de mulheres negras". Conforme registra a intensa produção intelectual dos feminismos negros brasileiros, a interseccionalidade não está restrita ao modo de perspectivar situações de violência produzidas contra mulheres negras, mas precisa estar na base do desenvolvimento de ações que visem ao agenciamento dessas posições com fins à promoção de processos de resistência feminista e antirracista.

No atual contexto brasileiro, especialmente com o advento e a onipresença das redes sociais, as práticas de ativismo digital impactaram/ impactam significativamente os modos de agência dos movimentos sociais e grupos de militância. São expandidos, assim, os limites da esfera pública na qual a sociedade civil pode se organizar e se mobilizar em favor de causas comuns (SCHERER-WARREN, 2006). A apropriação das tecnologias e mídias digitais por parte de grupos socialmente deslegitimados se constitui parte importante das dinâmicas de participação cidadã e de luta por direitos humanos (MAIA, 2018) na contemporaneidade. Conforme discute Braga 
(2010, 2015), ainda que o avanço no desenvolvimento dessas tecnologias não garanta a subversão dos modelos de estruturação social, "a diminuição de custos envolvidos no acesso à informação e à interação a distância viabilizados pela Internet ampliam, ou mesmo criam, novos espaços de participação social, os quais carregam em si um potencial transformador" (BRAGA, 2010, p. 374).

Inseridas nesse processo, práticas de ativismo digital correspondem a "toda estratégia que persegue a mudança da agenda pública, a inclusão de um novo tema na ordem do dia da grande discussão social, mediante a difusão de uma determinada mensagem e sua propagação" (UGARTE, 2008, p. 55). Nesse sentido, as ferramentas digitais de comunicação e as formas de interação que elas inauguram, ou diversificam, oferecem aos novos feminismos ${ }^{3}$ possibilidades de expansão de suas narrativas contestatórias em relação aos discursos dominantes. Esse fato se dá, particularmente, mediante "a produção de imagens, a guerrilha da comunicação, as inter-relações entre arte e política, [...] como possibilidades de reinventar as identidades por meio das novas tecnologias" (GARCIA, 2015, p. 55). Tais práticas se iniciam com a entrada dos coletivos feministas no ciberespaço, na década de 1990, inaugurando o chamado "ciberfeminismo" enquanto articulação estética, política e de comunicação para a emancipação e o empoderamento de mulheres (HARAWAY, 2009; NATANSOHN, 2013).

No contexto brasileiro, junto a diferentes formas de associação praticadas no espaço off-line que estendem sua militância para o espaço digital, o Geledés, Instituto da Mulher Negra, intitula-se como "uma organização da sociedade civil que se posiciona em defesa de mulheres e negros por entender que esses dois segmentos sociais padecem de desvantagens e discriminações no acesso às oportunidades sociais em função

\footnotetext{
${ }^{3} \mathrm{O}$ fato é que as redes digitais têm se tornado espaço de intensa presença dos feminismos, em suas mais variadas vertentes, ao ponto de algumas autoras se referirem a uma "quarta onda" do feminismo (de caráter eminentemente digital) ou ao feminismo enquanto um campo político-discursivo de ampla presença nas redes, ao invés de ser tomado nos termos descritivos clássicos de um movimento social (MARTINEZ, 2019). O que aqui estou referindo como novos feminismos são aqueles impulsionados pelas problematizações raciais e de sexualidade impostas a um sujeito universal do feminismo, "a mulher": branca, cisgênera, burguesa, heterossexual, capacitista. Exemplos dessas novas expressões contestatórias dos feminismos são os feminismos negros, os transfeminismos, os feminismos queer e afins.
} 
do racismo e do sexismo vigentes na sociedade brasileira" (GELEDÉS, 2018). Dentre as perspectivas de luta assumidas pela organização, fundada em São Paulo pela feminista Sueli Carneiro há mais de 30 anos, aparecem como pautas prioritárias de sua ação política e social "a questão racial, as questões de gênero, as implicações desses temas com os direitos humanos, a educação, a saúde, a comunicação, o mercado de trabalho, a pesquisa acadêmica e as políticas públicas" (GELEDÉS, 2018).

\section{FIGURA 1 - Página inicial da fanpage do Geledés no Facebook}

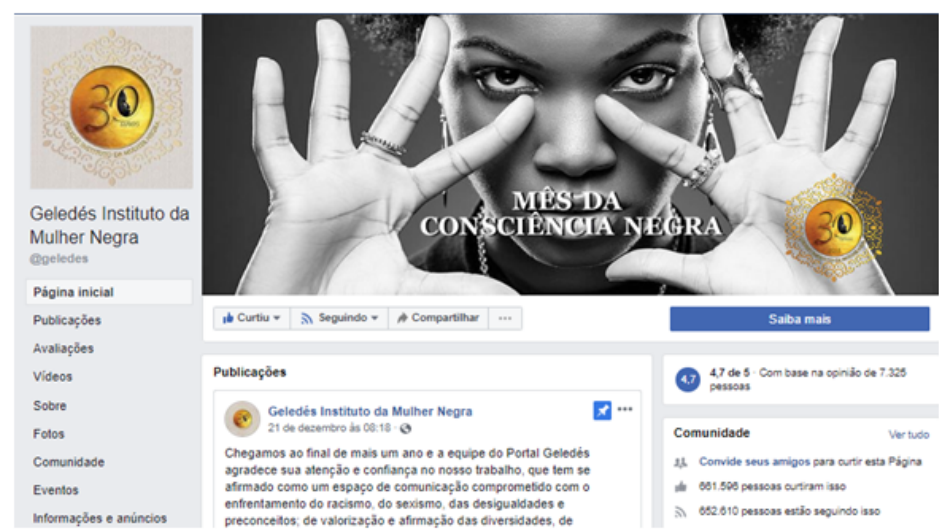

Fonte: Facebook (2018).

Na página do Geledés no Facebook (ver FIGURA 1), aqui tomada como um coletivo midiático de ativismo digital, são replicados conteúdos originalmente postados no portal ${ }^{4} \mathrm{da}$ instituição, bem como circulam conteúdos especificamente ligados às possibilidades de linguagem dessa rede, a exemplo dos cartazes digitais. Dessa forma, mediante as possibilidades de

\footnotetext{
${ }^{4}$ O portal da instituição (Disponível em: www.geledes.org.br. Acesso em: 16 set. 2020), além de servir para a divulgação de suas ações também no espaço off-line (a exemplo de cursos, palestras, lançamento de livros, manifestações de rua etc.), funciona como uma espécie de matriz de conteúdos de diferentes naturezas e linguagens para a militância que são, em geral, replicados em diferentes plataformas e nas suas redes sociais. A exemplo disso, o Geledés está inserido no Youtube, com um canal homônimo que conta atualmente com 2,9 mil inscritas(os). No Twitter, a página, ativa desde 2009, conta com 36,1 mil seguidores; já no Instagram, o número chega a 36,8 mil. No Facebook, a fanpage que contava, quando da realização desta pesquisa, com 661.593 curtidoras(es) e 652.610 seguidoras(es), confirmando-se como a rede social da organização com maior impacto.
} 
interação disponíveis na plataforma, o fluxo de informações, os materiais de conscientização e a visibilização de narrativas que tensionam as fronteiras do pensamento colonial, a fanpage constitui-se como arena de militância e espaço de formação e empoderamento de mulheres negras para o enfrentamento de seus desafios diários em relação aos efeitos concretos da intersecção entre racismo e sexismo, como apontam participantes ligadas ao coletivo e engajadas nesses espaços de ativismo digital. ${ }^{5}$

\section{Gênero e raça em perspectiva performativa}

Segundo perspectivas antiessencialistas ou queer, a exemplo daquela defendida por Butler (2017), isto que comumente é nomeado de "identidade" corresponde a um produto cumulativo, e permanentemente em processo de implementação, do uso que fazemos cotidianamente, em contextos situados e de forma reiterada, de uma gama de recursos semióticos, a exemplo de elementos verbais, corporais, gestuais, de vestimenta, dentre outros, os quais produzem para nós um lugar, um efeito identitário. Nesse sentido, "a essência ou a identidade que por outro lado pretendem expressar são fabricações manufaturadas sustentadas por signos corpóreos e outros meios discursivos" (BUTLER, 2017, p. 235, grifo da autora).

Em face desse modelo performativo de identidade proposto por Judith Butler, em muito tributário da visão de linguagem como forma de ação, elaborada por John L. Austin (1975) e revisada por Jacques Derrida (1991), as ações dos indivíduos não emergem de uma subjetividade interior, mas é justamente a repetição ininterrupta dessas ações, dessas performances, que produz efeitos de estabilidade. Nesse viés, a aparência da identidade como uma realidade natural e essencial, uma dimensão ontológica, da ordem do ser ("ser homem", "ser mulher", "ser heterossexual", "ser negro", "ser negra" e afins), se produz a reboque de uma "metafísica da substância” (BUTLER, 2017, p. 49), a qual escamoteia, para fins que servem às disputas de poder inscritas na estabilidade/instabilidade das identidades e às hierarquizações da vida que daí emergem, seu caráter inelutavelmente artificial. Em outras palavras, o que é chamado de identidade é, na verdade, produto da repetição de performances histórica e culturalmente localizáveis, imiscuídas em relações de poder.

\footnotetext{
${ }^{5}$ Conforme disponível em: https: / $/$ www.youtube.com/watch?v $=\mathrm{u}-\mathrm{XfJ} f d e P t c \& t=219 \mathrm{~s}$. Acesso em: 11 jan. 2019.
} 
É no influxo dessas posições que se pode entender o gênero como uma instância performativa, "a estilização repetida do corpo, um conjunto de atos repetidos no interior de uma estrutura reguladora altamente rígida, a qual se cristaliza no tempo para produzir a aparência de substância, de uma classe natural de ser" (BUTLER, 2017, p. 69). Assim, performances de gênero sempre se realizam no interior de instâncias marcadas pelo poder e pelas disputas de poder, como pensado por Foucault. Tal alusão, conforme discute Borba (2014), livra-nos do equívoco do voluntarismo. Ou seja, aquele de encarar a performatividade como uma afirmação da total liberdade do sujeito em produzir identidades como lhe bem aprouver, ao sabor de escolhas pretensamente ligadas à ordem da consciência e da racionalidade.

Em desfavor dessa concepção enviesada, em boa parte tributária da confusão entre performance e performatividade feita por segmentos feministas insatisfeitos com as desterritorializações conceituais pósestruturalistas, a própria Butler adverte que "a performatividade não é nem jogo livre nem auto-apresentação [sic.] teatral; nem pode simplesmente ser igualada ao desempenho" (BUTLER, 1993, p. 33). Tal asserção abre caminhos para se pensar nas contingências culturais e históricas discursivamente implicadas na elaboração das performances identitárias de gênero (e também de raça, dentre outras), o que se realiza em face de marcos de inteligibilidade e reconhecimento situadamente negociados.

Ao tomar as identidades de gênero e de raça como performances, estou assumindo, por outro lado, que, não sendo o corpo um dado transparente ou dotado de uma significação imanente, ele é, também, um signo produzido contextualmente. É nesse sentido que estruturas anatomofisiológicas, ou mesmo elementos corporais, fisionômicos, capilares, não se constituem na exterioridade de narrativas culturais específicas, ainda que sejam de caráter médico ou científico - as quais se querem pretensamente imunes ao influxo de diferentes ordens do discurso e suas contingências históricas. Ao contrário, penso no sentido de uma incorporação, da encarnação discursiva de um corpo-efeito, pondo em relação de contiguidade e de inseparabilidade práticas discursivas e práticas corporais.

Nesses termos, é possível pensar que atos de fala, graças ao seu potencial performativo, materializam efeitos de diferenciação social nos corpos, produzidos no interior de marcos discursivos específicos. Por isso, textos, enquanto configurações semióticas assumidas pelos atos de fala, estão intrinsecamente relacionados aos corpos, em suas relações de 
identidade e diferença (PINTO, 2015; PINTO; AMARAL, 2016). Mais ainda, ao imiscuirmos tais dinâmicas nos quadros de regulação nos quais as performances situadas acontecem (a performatividade), tais marcações de diferenças corpóreo-discursivas estabelecem classificações e hierarquias, as quais respondem a construtos históricos sedimentados e aos amálgamas semióticos empregados na sua atualização, em práticas comunicativas situadas. É nesse sentido que "trajetórias textuais e situações comunicativas estão sempre articuladas com trajetórias corporais e corpos situados" (PINTO, 2015, p. 217).

Pensando numa economia das vidas estabelecida no Brasil, certamente a existência linguística de corpos racializados e generificados como corpos de negras e negros é, sem dúvida, aquela que ocupa a parte inferior do limiar da abjeção racial e de gênero. Nesse sentido, tais processos de hierarquização, altamente presentes no aqui e no agora da sociedade brasileira, estão articulados aos trânsitos particulares de signos e corpos que atravessam a história nacional, especificamente no que diz respeito ao seu período colonial e às suas insistentes formas de permanência e de atualização. Vale lembrar que, no contexto do Atlântico Negro, como definido por Gilroy (2012), o Brasil é o país em que a conivência formal ${ }^{6}$ com a escravização de pessoas negras, forma limítrofe de extenuação injuriosa do corpo, durou mais anos no mundo, vigorando durante três séculos.

Sob essa perspectiva, a raça se constitui como um instrumento político (performativo) utilizado por grupos hegemônicos que instituem a si mesmos como não marcados nesses termos, brancos, no interior de um arranjo de poder que lhes autoriza universalizar sua própria posição. Em função de legitimar essa operação, produzem espaços de subordinação e inferiorização nos quais determinados grupos, aqueles de quem se quer dispor, então

\footnotetext{
${ }^{6}$ Aqui me refiro à "conivência formal", pois estou de acordo com autoras como Ângela Davis e Lélia Gonzalez, quando, em suas perspectivas abolicionistas, encaram o fator racial implicado em fenômenos sociais, como o encarceramento em massa de pessoas negras, o extermínio da juventude negra, os entraves no acesso à educação formal, a produção da pobreza e de condições de desemprego e trabalho precários, além do trabalho escravo contemporâneo, sendo essas formas de continuação histórica da escravidão, dentro de marcos tidos, por vezes, legal e moralmente como legítimos, mesmo em Estados que se reconhecem, do ponto de vista formal, como estados democráticos de direito, nos quais há, em tese, pleno gozo de igualdade perante a lei entre seus cidadãos e em face do alegado cumprimento de prerrogativas nacionais e internacionais de direitos humanos.
} 
obliterados de sua condição reconhecível de humanidade, são produzidos enquanto "Outros". Vale dizer que parte importante desse funcionamento é o efeito de escamoteamento que encobre tais jogos de poder, mediante a naturalização de discursos e violências raciais, tornando-se indispensável para sua eficácia e reiteração a aparente naturalidade de que gozam.

Em termos práticos, os efeitos nefastos de processos de racialização podem ser sentidos em instâncias que vão desde a segregação da circulação espacial de corpos no interior de fronteiras urbanas e internacionais, passando pela suspensão sistemática de direitos humanos, sociais e políticos, chegando até a concretização da última instância de negação do próprio estatuto de humanidade: a autorização estrutural e sistêmica da violência, quer em sua modalidade física (violência policial e extermínio da juventude negra, por exemplo), quer em sua modalidade simbólica (línguas, religiões, culturas, dentre outros).

Sistemas coloniais de dominação constituíram os termos desses padrões de poder baseados em processos de hierarquização que se reconfiguram e se perpetuam nas relações sociais e econômicas dos povos colonizados. Isso se dá por meio de ideologias, padrões discursivos e desigualdades materiais que se estendem para além de momentos históricos específicos dos processos formais de colonização, no que se tem chamado de "colonialidade" (MIGNOLO, 2017; QUIJANO, 2005). Nos termos das práticas linguísticas discutidas neste artigo, os corpos inferiorizados no cruzamento de hierarquias racial e de gênero vigentes são os corpos das mulheres negras, aqueles cuja condição de subtração do traço humano, e de qualquer dignidade que este lhe outorgue, pode ser ouvida nas palavras de Fanon (2008, p. 103): “cheguei ao mundo pretendendo descobrir o sentido nas coisas, minha alma cheia de desejo de estar na origem do mundo, e eis que me descubro em meio aos objetos".

Como parte de um processo mais amplo de fabricação discursiva de vidas e corpos negros sob o signo da despersonalização e da inferiorização, a "raça" é então tomada, na linguagem colonizadora, como uma categoria definidora suprema, uma supracategoria homogeneizante e reificante, da qual outras categorias são simples traços. Nisso, as corporeidades racializadas são produzidas enquanto efeitos de atos performativos linguísticos e corporais racistas, uma vez que "o fenótipo negro" passa a ser essencializado e estereotipado, produzido, assim, segundo uma estética corporal da abjeção racial, a qual possui papel particular na manutenção simbólica e na vigilância 
das fronteiras políticas do binarismo constituído entre os corpos marcados em termos de raça, o negro, e o não marcado, o branco.

$\mathrm{Na}$ multiplicidade de ordens de discurso que disputam o significado das práticas identitárias de raça, aquela relativa a uma pretensa harmonia das raças passou a servir como fundamento central da crença em uma democracia racial (NASCIMENTO, 2016), estabelecida no Brasil em defesa de uma almejada paz social, fundamento de um ideário de uma sociedade harmonicamente miscigenada, plural, na qual todos são bemvindos e as diferenças são valorizadas. Ao contrário disso, conforme discute Muniz (2016, p. 14, grifo da autora), observa-se "o projeto de diluição das diferenças entre as raças para obter uma unificação nacional e, assim, diluir também o poder político de quem historicamente foi visto e tratado como diferente igual a desigual". Nesse contexto de apagamento das diferenças raciais, a lógica do branqueamento toma o corpo negro como um espaço a ser normalizado pelos supostos marcos corporais de uma estética política e subjetiva "branca", em que a "branquitude" se refere a "um lugar de poder, de vantagem sistêmica nas sociedades estruturadas pela dominação racial" (SCHUCMAN, 2012, p. 102), fundado a partir de "estereótipos que convergem o 'negro' na negação do 'branco' ou na própria imagem do 'antibranco"' (FERNANDES, 2014, p. 165).

Em função de uma perspectiva antiessencialista de linguagem e das identidades, pensar a raça, assim como o gênero, enquanto instâncias performativas, significa que o processo de produção do corpo racializado, ${ }^{7}$ no caso deste trabalho, racializado como corpo negro, realiza-se mediante a repetição reiterada de atos de fala/atos de corpo (PINTO, 2002) que produzem os marcos hegemônicos da inteligibilidade racial, bem como as possibilidades de sua subversão. Esses se constituem no interior de espectros normativos sustentados por regimes semióticos mais densos, os quais

\footnotetext{
${ }^{7}$ Aqui, gostaria de chamar atenção para o fato de que, longe de produzir um posicionamento binarista entre experiências de racialização, de branquitude e de negritude, por exemplo, busco afirmar que tal processo opera mediante o efeito performativo de semioses várias, as quais produzem o corpo como um efeito mediado por uma miríade de gradientes políticos de leitura, os quais são históricos, sociais, culturais. Desse modo, diferentes processos de racialização, para além do espectro aqui discutido, podem ser tomados sob esse prisma, a exemplo dos significados raciais nos quais corporalidades indígenas podem ser produzidas. A ênfase na questão racial concernente à branquitude e à negritude, neste trabalho, justificase naquilo que os dados gerados a partir do material de análise me permitem discutir.
} 
significam insistentemente os sujeitos racializados em face de estereótipos veiculados num sem-número de práticas de produção de sentidos - a exemplo de expressões populares, piadas, discursos sobre sexualidade/ corporalidade, produtos culturais diversos, dentre outros.

Nesses termos, a performatividade de raça pode, assim, por meio da repetição paródica (BUTLER, 2017), no jogo entre identidades e diferenças, subverter performances estereotipadas, naturalizadas socialmente sobre pessoas negras. Tal possibilidade fornece as condições para o tensionamento das fronteiras do discurso colonial com vistas à produção de significados antirracistas, uma vez que não há um discurso ou uma performance original do "ser negro(a)" em questão, apenas as repetições sucessivas de performances, gerando o efeito de uma pretensa performance racial original. Nesse sentido, o diálogo entre perspectivas acerca da dimensão performativa do corpo, enquanto signo produzido na intersecção de diferentes marcadores sociais da diferença, permite perspectivar também a questão racial (para além de gênero e outros), desmantelando discursos essencialistas que tomam pessoas negras como portadoras de uma identidade racial estável e cristalizada, quase sempre manejada para fins racistas e excludentes.

Pensando na complexidade em que a vida social se produz, certamente os efeitos performativos que produzem os corpos mediante a projeção discursiva de marcadores sociais de raça não se dissociam daqueles que materializam marcadores sociais de gênero (o mesmo se aplica para sexualidade, classe, dentre outros, ainda que não ocupem o foco desta reflexão). Nesse contexto, pensar o modo como marcadores sociais de diferentes ordens se interseccionam na elaboração das subjetividades, dos corpos e das relações sociais, tem sido cada vez mais priorizado nas pesquisas, haja vista que tal perspectiva reduz o caráter de artificialidade do modo como concebemos questões sociais, isoladas sob lentes de epistemologias específicas, passando a enfatizar a complexificação desses fenômenos em face dos múltiplos atravessamentos de poder que os constituem. Esse exercício aproxima nossas considerações acadêmicas do que se vive efetivamente, uma vez que ninguém experiencia exclusivamente e "uma por vez", ou do mesmo modo, cada uma das categorias sociais nas quais nossos corpos são produzidos. 


\section{A produção de identidades na/pela linguagem: posicionamentos interacionais e pistas indexicais}

Conforme discute Cameron (1997), diferentemente de abordagens tradicionais da sociolinguística, as quais assumem que as pessoas falam de um certo modo em consequência do que elas (já) são, perspectivas pósestruturalistas e queer que investigam a relação entre linguagem, identidade e marcadores sociais da diferença sugerem que "as pessoas são quem são por causa (dentre outras coisas) da maneira como falam” (CAMERON, 1997, p. 49). Assim, toma-se esse "falar" como uma metáfora em relação ao emprego situado de recursos semióticos em diferentes contextos interacionais para a produção de performances identitárias.

Nesse sentido, no interior do conjunto de formas de agência que sustentam os efeitos identitários, "a linguagem é sem dúvida elemento fundamental, porque as ações não linguísticas que postulam o sujeito, quando descritas, são ao mesmo tempo repetidas nos atos de fala que as descrevem" (PINTO, 2007, p. 16). Em outras palavras, a linguagem não reflete de forma especular o lugar social de quem fala, mas constitui esse lugar, de modo que "a repetição é necessária para sustentar a identidade precisamente porque esta não existe fora dos atos de fala que a sustentam" (PINTO, 2007, p. 16).

Interpeladas por essas perspectivas performativas e situadas em produção das identidades na/pela linguagem, Mary Bucholtz e Kira Hall (2005), realizando um trabalho que cartografa múltiplas contribuições advindas de diferentes áreas das ciências humanas acerca do estudo das identidades, argumentam, de uma perspectiva que nomeiam como linguística sociocultural, sobre a natureza radicalmente situada, local e interacional, nas identidades. Nessa visada, assumem que "o processo de construção da identidade não reside no indivíduo, mas nas relações intersubjetivas de identidade e diferença, realidade e falsidade, poder e desempoderamento" (BUCHOLTZ; HALL, 2005, p. 607, tradução nossa), as quais, enquanto formas de agência que extrapolam a ação como prática individual e deliberada, chamam atenção para "a miríade de formas pelas quais a identidade passa a existir, da prática habitual à negociação interacional, às representações e ideologias" (BUCHOLTZ; HALL, 2005, p. 607, tradução nossa). 
Sustentando que a "identidade é o posicionamento social de si e do outro” (BUCHOLTZ; HALL, 2005, p. 586, tradução nossa), dentre cinco princípios, ${ }^{8}$ segundo os quais as relações entre linguagem e identidade podem ser consideradas, as autoras elencam o princípio do posicionamento, o qual destaca-se de modo particular nesta pesquisa justamente por fornecer perspectivas produtivas para se pensar as performances de gênero e raça produzidas em contextos interacionais on-line, mediante o estabelecimento de posicionamentos interacionais. Tal princípio sustenta que as identidades englobam: “(a) categorias demográficas de nível macro; (b) posições culturais locais, etnograficamente específicas; e (c) posições temporárias e interacionalmente específicas e papéis dos participantes" (BUCHOLTZ; HALL, 2005, p. 592, tradução nossa).

Partindo disso, fica saliente o modo como, em interações situadas, a produção de identidades se dá mediante uma relação complexa de negociação de posições, pondo em jogo elementos de diferentes escalas, a exemplo dos significados partilhados: de categorias macrossociais como gênero, raça, classe; de elementos locais de ordem cultural, ou do modo como as categorias macrossociais são representadas no contexto de cultura específico no qual a cena interacional se desenrola; e, por fim, das posições específicas assumidas/rejeitadas/redefinidas pelos(as) participantes no curso da interação discursiva, frente à negociação de seus papéis.

É nesse sentido que Davies e Harré (1990) propõem que posicionamentos interacionais correspondem ao processo discursivo por meio do qual pessoas são localizadas numa conversa específica como participantes que, de modo coerente e conjunto, produzem linhas de história (storylines). Para esses autores, "qualquer narrativa que desenvolvemos colaborativamente com outras pessoas baseia-se [...] no conhecimento das estruturas sociais e nos papéis que são reconhecidamente atribuídos às pessoas dentro das estruturas" (DAVIES; HARRÉ, 1990, p. 52, tradução nossa). Assim, vale ressaltar que "estruturas sociais são coercitivas na medida em que, para ser reconhecível e aceitavelmente uma pessoa, devemos operar dentro de seus termos" (DAVIES; HARRÉ, 1990, p. 52, tradução nossa).

\footnotetext{
${ }^{8}$ Além do princípio do posicionamento, as autoras também apontam o princípio da emergência, o princípio da indexicalidade, o princípio da relacionalidade e o princípio da parcialidade. Para uma leitura mais detida sobre o assunto, ver Bucholtz e Hall (2005).
} 
Por essa visada, os autores abrem espaço para se pensar na correlação entre posicionamentos interacionais e performances identitárias situadas, na medida em que reconhecem a força constitutiva do discurso e, de modo específico, das práticas discursivas, sem se desconsiderar que as pessoas são, no interior desses contextos, capazes de exercer agenciamentos em relação a essas mesmas práticas. Assim, apostando num olhar que privilegie o nexo micro/macro tanto das práticas sociais quanto dos seus modos de investigação, a produção de performances identitárias pode ser produzida/ interpretada a partir da mobilização de posicionamentos interacionais, os quais se dão diante de "uma posição de sujeito disponibilizada dentro de um discurso" (DAVIES; HARRÉ, 1990, p. 53, tradução nossa). Nesse sentido,

um indivíduo emerge através dos processos de interação social não como um produto final relativamente fixo, mas como aquele que é constituído e reconstituído através das várias práticas discursivas de que participa. Assim, quem é alguém é sempre uma questão aberta, com uma resposta variável dependendo das posições disponibilizadas dentro das nossas próprias práticas discursivas e das práticas discursivas dos outros e, dentro dessas práticas, das histórias através das quais produzimos sentido para nossa própria vida e para a de outras pessoas. (DAVIES; HARRÉ, 1990, p. 45, tradução nossa)

Enfatizando que os posicionamentos interacionais analisados neste artigo se realizam em contextos de militância social de grupos feministas negros, como é o caso da página do Facebook e do blog do Geledés, é interessante destacar o papel que determinados recursos linguísticos desempenham na produção das performances identitárias de raça e de gênero. Isso, porém, só se torna possível mediante uma compreensão de língua(gem) que se afaste de uma visão meramente pautada nas ideias de sistema ou de estrutura para, de uma visada pragmática e socioantropológica, considerá-la enquanto repertório semiótico interacionalmente mobilizado em práticas discursivas. Estas, por sua vez, tomadas como atividades locais de significação, estão sempre articuladas a processos sociais, culturais e históricos mais amplos, em vias de constante negociação intersubjetiva entre aqueles que delas participam. Tal princípio de indexicalidade (BLOMMAERT, 2005; SILVERSTEIN, 2003) dos signos atenta para o fato de que significados sociais, posições interacionais e performances identitárias produzidas em interações localizáveis apontam para um conjunto 
de convenções macrossociais, as quais não são totalmente compreendidas nesses eventos, uma vez que os ultrapassam e os antecedem (AGHA, 2007; FABRÍCIO, 2013).

Partindo dessas posições, com vistas a viabilizar o expediente analítico deste trabalho, é acionada a proposta de Wortham (2001) acerca das pistas indexicais, as quais funcionam como elementos que indiciam os processos de articulação entre arranjos semióticos locais (neste caso, linguísticos) e aqueles macrossociais. De modo específico, tomarei como categorias analíticas três (referência e predicação, citação e índice avaliativo) das cinco pistas por ele propostas, ${ }^{9}$ sendo essas as que se tornaram mais produtivas em relação ao material de análise.

QUADRO 1 - Pistas indexicais empregadas na mobilização de posicionamentos interacionais conforme Wortham (2001)

\begin{tabular}{|c|l|}
\hline $\begin{array}{c}\text { Referência e } \\
\text { predicação }\end{array}$ & $\begin{array}{l}\text { Dizem respeito ao modo específico de selecionar e nomear as coisas do } \\
\text { mundo, bem como de classificá-las ou caracterizá-las, respectivamente. Desse } \\
\text { modo, ao nomear coisas, sujeitos, situações, processos, e também ao predicá- } \\
\text { los, o narrador posiciona a si mesmo e identifica as personagens, nomeadas } \\
\text { e predicadas, socialmente. }\end{array}$ \\
\hline Citação & $\begin{array}{l}\text { Tal prática pode se realizar, na elaboração de um posicionamento, mediante: } \\
\text { (1) citação direta, ou seja, o expediente de recriar, reelaborar o que foi } \\
\text { enunciado por outra personagem; e (2) citação indireta, ou seja, quando } \\
\text { o participante reconta em suas próprias palavras o que fora dito por outra } \\
\text { personagem. }\end{array}$ \\
\hline Índices \\
avaliativos & $\begin{array}{l}\text { Esses elementos indexicais cumprem a função de identificar/posicionar } \\
\text { seu(sua) enunciador(a) como parte de um dado grupo social. Em geral, } \\
\text { tal processo pode se dar por meio de estereótipos produzidos pela ligação } \\
\text { de tipos específicos de pessoas a tipos específicos de enunciados. Pode-se } \\
\text { recorrer a expedientes como a ironia. }\end{array}$ \\
\hline
\end{tabular}

Fonte: Elaboração própria a partir de Wortham (2001).

Embora Wortham (2001) tenha desenvolvido a proposta das pistas indexicais enquanto categorias analíticas para a compreensão de narrativas autobiográficas, tal proposta tem sido amplamente recontextualizada no

\footnotetext{
${ }^{9}$ Dentre as cinco pistas indexicais propostas por Wortham (2001), ficaram de fora do quadro elaborado, pelos motivos já apresentados, os descritores metapragmáticos e os modalizadores epistêmicos.
} 
escopo de pesquisas em Linguística Aplicada que se debruçam sobre a análise de diferentes práticas interacionais de caráter identitário, realizadas em contextos diversos, especialmente naqueles relativos às práticas digitais de interação (GONZALEZ; MOITA LOPES, 2015; GUIMARÃES; MOITA LOPES, 2016, 2017; MELO; MOITA LOPES, 2015).

\section{Aspectos metodológicos e contexto de pesquisa}

Partindo de uma perspectiva de pesquisa em Linguística Aplicada indisciplinar, (MOITA LOPES, 2006, 2009; FABRÍCIO, 2017), é levada em conta a necessidade de transgredir fronteiras estaques dos campos disciplinares, com vistas a repensar as crenças modernistas/positivistas em torno da elaboração do conhecimento. No concurso dessa opção, tal encaminhamento afeta de modo fulcral o desenho epistemológico dos trabalhos desenvolvidos, problematizando a relação entre teoria e prática, no sentido de "avançar na produção de conhecimento ao mesmo tempo em que também politizam-se as práticas sociais ou para a premência de fazer pesquisa e fazer política conjuntamente" (MOITA LOPES, 2009, p. 35).

Desse modo, como discute Fabrício (2017) acerca da radicalização da proposta de INdisciplinaridade no campo aplicado dos estudos da linguagem, fica evidente que "esse esforço descentralizador também envolve revisitar e reinventar procedimentos metodológicos, a conexão entre sujeito e objeto de pesquisa, e a relação com o processo de produção de conhecimento" (FABRÍCIO, 2017, p. 613). E isso num compromisso cada vez mais explícito de compreender, de modo sempre contingente, a participação da linguagem na vida social, abrindo-se, por isso, às redescrições (MOITA LOPES, 2006) necessárias e à escuta de vozes alternativas em relação àquelas hegemônicas na elaboração do conhecimento sobre os outros, desvencilhando-se de modos ocidentalizados, com vistas a ouvir "outras narrativas, aquelas normalmente apagadas no decorrer da modernidade, como as dos pobres, mulheres, indígenas, negros, homossexuais etc.” (MOITA LOPES, 2009, p. 37).

Assim, do ponto de vista metodológico, os dados analisados neste artigo foram gerados a partir da observação não participante realizada em uma comunidade de prática on-line, engajada no ativismo digital de feminismos negros, a fanpage do coletivo Geledés, na rede social digital Facebook. O período de observação a partir do qual tais dados foram 
gerados se desenrolou entre junho e dezembro de 2018, guiando-se pelas perspectivas da Etnografia Virtual (HINE, 2002), a qual ressignifica pressupostos básicos da abordagem etnográfica, como praticado na Antropologia, com a finalidade de investigar contextos on-line de interação na sua relação com aqueles off-line.

Desse modo, há que se ressaltar os deslocamentos espaço-temporais produzidos pela observação de interações que se desenrolam em redes digitais, no sentido de que a etnografia praticada nesses espaços nunca é holística, mas sempre parcial, devendo-se, então, abandonar pressupostos de descritibilidades totalizantes, de forma que a amostragem do material de pesquisa é sempre intencional, e sua análise, bastante flexível. Nesse sentido, acredita-se ser essa proposta bastante afinada com o objetivo de produzir inteligibilidades contingentes acerca de performances identitárias de gênero e de raça a partir do posicionamento interacional dos(as) participantes das seções de comentários da página de ativismo digital focalizada.

\section{Posicionamentos interacionais e reflexividade no ativismo digital de Geledés: análises}

Com vistas a aprofundar e aplicar as incursões teóricas até aqui realizadas, é apresentado, nesta seção, um extrato da análise de comentários de seguidores(as) da página de ativismo digital do coletivo Geledés no Facebook, com vistas a interpretar como as performances de gênero e raça são (re)elaboradas mediante posicionamentos interacionais mobilizados pelos(as) comentadores(as). Nesse sentido, dada a pauta política levantada pelo texto "Você amaria uma mulher negra?", de Fernanda Rodrigues de Figueiredo, replicada do portal do coletivo , os comentários analisados projetam posicionamentos acerca da solidão afetiva de mulheres negras em face do racismo estrutural, na sua intersecção com o gênero, que as significa como destinadas para práticas sexuais informais, sendo, assim, preteridas pelos homens no que tange a relações românticas. As conotações políticas dessas vivências, que parecem demasiado individuais à primeira vista, são enfatizadas pela autora.

Como exceção a essa tendência, serão discutidos os sentidos de uma interação direta entre comentadoras(es), pondo em evidência posicionamentos interacionais interpessoais. Na organização dos comentários nesta seção, foi respeitada a ordem cronológica de sua postagem 
na página, bem como mantidas eventuais marcas de escrita próprias de interações em espaços digitais, haja vista ter optado pela geração de imagens por meio de captura de tela (print screen). Ademais, considerando a natureza pública, em termos de políticas de privacidade, das postagens da página e dos comentários analisados, foi escolhido reproduzi-los conservando suas características gráficas originais, porém tornando inidentificáveis as fotos e os nomes dos(as) comentadores(as), os quais foram substituídos por nomes fictícios, respeitando-se a expressão de gênero indicada pelos participantes em seus perfis.

A seguir, reproduzo a referida postagem, de 2 de dezembro de 2018, na qual os(as) comentadores(as) se engajam. Ela gerou 411 reações, 91 compartilhamentos e 43 comentários, dentre os quais estão os aqui analisados. Das formas de engajamento de usuários(as) disponíveis na plataforma Facebook, o comentário, conforme discutem Bertucci e Nunes (2017, p. 11), pode ser considerado uma interação que registra o grau mais elevado de envolvimento, haja vista se tratar de um outro texto "que revela o percurso construído pelo leitor e que soma outros sentidos ao primeiro".

FIGURA 2 - Replicação do texto "Você amaria uma mulher negra?"

\title{
Geledés Instituto da Mulher Negra
}

2 de dezembro às 11:47.

\begin{abstract}
"Para refletir sobre essa pergunta, pensemos em três "arestas": amar (verbo), a negra/preta (numa sociedade racista misógina e violenta) e a coragem revolucionária. Amar é verbo o que explicaria ser ativo: palavra que designa ação. Portanto, ninguém ama sem se posicionar." \#geledes \#mulherengra
\end{abstract}

GELEDES.ORG.BR

Você amaria uma negra? - Geledés

Por Fernanda Rodrigues de Figueiredo* para 0 Portal Geledés Amar uma mulher negra é um ato essencialmente revolucionário. Não é qualquer umx que tem coragem para assumir isso. A

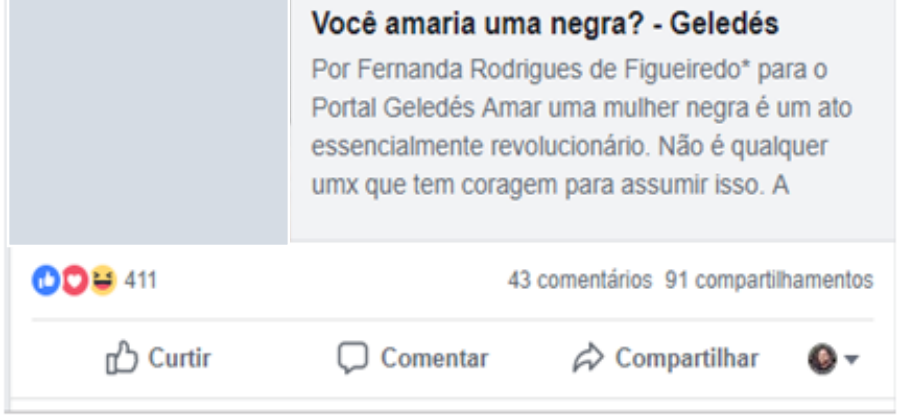

Fonte: Facebook (2018) 
FIGURA 3 - Comentário sobre o texto "Você amaria uma mulher negra?" no Facebook

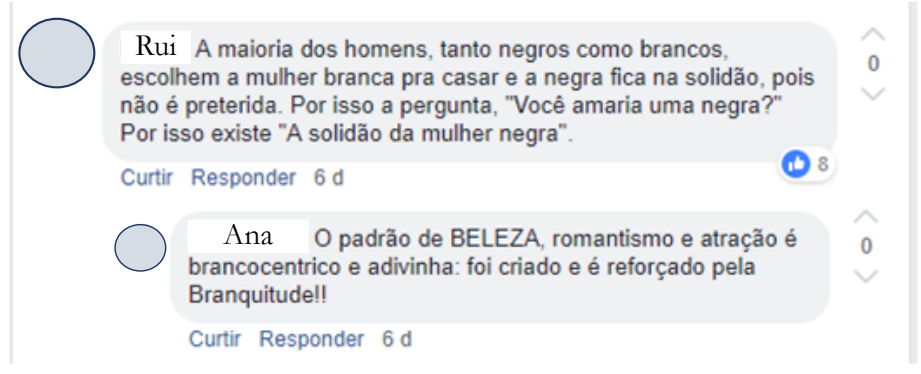

Fonte: Facebook (2018).

De certo modo, o comentário elaborado pelo participante Rui, na Figura 3, realiza uma citação indireta do conteúdo desenvolvido pela postagem, uma vez que narra, segundo suas palavras, as ideias acerca da exclusão afetiva que mulheres negras experienciam em suas relações amorosas como fruto da intersecção entre marcadores de gênero e raça. Ao realizar essa citação, são acionados modos de nomear/referenciar sujeitos e processos implicados na situação narrada que projetam posicionamentos interacionais favoráveis à discussão racial e de gênero nos termos da matéria. Ao elaborar o ato de fala "a maioria dos homens, tanto negros como brancos, escolhem a mulher branca para casar enquanto a negra fica na solidão", o participante aciona processos de nomeação e predicação que, ao invés de escamotearem marcações de gênero (homens / mulheres) e de raça (negros/brancos), o que poderia acontecer por meio de predicações aparentemente neutras como "pessoas", "seres humanos", evidenciam processos de exclusão que ocorrem entre sujeitos generificados e racializados, chamando atenção para posições de prestígio e desprestígio produzidas por essas performances identitárias na organização das relações afetivas.

Nesse sentido, ao predicar a categoria de gênero "homens" como aquela a quem é outorgada a agentividade no processo de seleção de parceiros(as), uma vez afirmando que "homens [...] escolhem mulheres", o participante sinaliza o reconhecimento crítico de uma hierarquia entre as performances de gênero na qual os sujeitos lidos como homens são postos em condição de privilégio, de superioridade, marcada no poder caracterizado pela capacidade de agência que lhes é atribuída, enquanto 
as mulheres são significadas como aquelas que são alvo de uma ação de seleção dos homens. Vale salientar que tais pistas indexam, ainda, discursos que projetam como único horizonte possível relações afetivo-sexuais entre os homens e as mulheres, reproduzindo, assim, uma lógica que, além de sexista, é heteronormativa, ou seja, silencia outros modos de existir e desejar fora de normas heterossexuais.

Atentando para outras pistas indexicais instadas no posicionamento interacional do comentador em questão, de modo especial, movendo nosso olhar dos processos de referência, que marcam aspectos identitários de gênero, para as predicações, as quais projetam diferenças raciais, é possível indicar o funcionamento de uma hierarquização interseccionada à outra, gerando, desse modo, uma desigualdade duplamente conjuntural entre ambos os marcadores. No que tange às predicações que significam e diferenciam as performances raciais de homens e mulheres enquanto brancas(os) e negras(os), o comentário de Rui chama atenção para o fato de que, mesmo significado em categorias raciais distintas e hierarquizadas entre si (brancos/negros), no que tange ao exercício de uma relação afetiva objetal para com as mulheres negras, o pertencimento a uma categoria de gênero privilegiada, a categoria sinalizada pela predicação homens, sobrepuja as diferenças raciais.

Marcam-se, então, ainda que de modo indireto, as referências e as predicações mobilizadas como índices avaliativos, uma vez que sinalizam a potencialidade de homens negros, bem como brancos, agirem como reprodutores do racismo estrutural imiscuído nas relações afetivo-sexuais entre homens e mulheres, como fica destacado no excerto "a maioria dos homens, tanto negros como brancos, escolhem a mulher branca para casar e a negra fica na solidão". Nesses termos, a performance discursiva do comentador informa o reconhecimento de como as diferenças e as hierarquias sociais são produzidas na e pela interação entre diferentes marcadores, de modo que, no interior de um mesmo grupo performativamente produzido pela projeção de marcadores raciais, a exemplo dos "negros(as)", marcadores de gênero podem posicionar homens negros em condições contingentes de relativa superioridade em relação a mulheres negras, no que tange ao exercício da liberdade de escolha afetivo-relacional, por exemplo.

Os sentidos indexicalizados pelos recursos semióticos que constituem o posicionamento interacional de Rui aludem ao fato de que o racismo sobreposto ao sexismo/machismo é capaz de produzir uma condição de 
"desempoderamento" (CRENSHAW, 2002, p. 10) particular, que diferencia sujeitos intergrupal (mulheres $\times$ homens) e intragrupalmente (mulheres negras $\times$ homens negros). Do ponto de vista dos processos de significação em jogo no seu discurso, é possível compreender como o emprego situado nos itens linguísticos, aqui considerados em função de sua participação na elaboração de performances identitárias interseccionais, está relacionado com significados normativos e hierárquicos que constituem uma gestão desigual das vidas em termos de gênero e de raça. Em outras palavras, a prática discursiva é aqui significada enquanto "uma realização interacional durante a qual processos locais de negociação de sentidos indexicalizam processos socioculturais mais amplos" (FABRÍCIO, 2013, p. 155).

Ainda analisando as pistas indexicais de que lança mão o participante Rui, é interessante notar o nexo causal estabelecido entre o modo de agência dos sujeitos referenciados e predicados, em seu comentário, como "a maioria de homens negros e brancos", e a condição a que mulheres negras são relegadas, como registrado nas predicações destacadas em "e a mulher negra fica na solidão, pois não é preterida”. Nesse sentido, novamente a condição de objetificação à qual é exposta a mulher negra (CARNEIRO, 2003, p. 10) numa lógica afetivo-relacional pautada na intersecção racismo/sexismo é caracterizada, no primeiro destaque, pela agentividade que revela o processo verbal, bem como pela nomeação do lugar afetivo e político que é relegado à mulher negra, a solidão. Já na segunda pista indexical destacada, a mulher negra é avaliada como aquela que não é preferida, certamente em comparação à mulher branca, graças ao não atendimento aos requisitos estéticos/políticos racistas e coloniais, os quais orientam e moldam desejos e escolhas de/por parceiros(as). Isso numa sociedade em que historicamente mulheres negras são coadjuvantes na cena dos relacionamentos socialmente legitimados, cujos corpos estão destinados aos prazeres bestiais e subterrâneos, úteis para o gozo, mas impensáveis para relações públicas. Desse modo, vê-se como se desenha uma geografia afetivo-relacional racista e sexista, na qual as mulheres negras têm seus corpos (re)produzidos nas práticas linguísticas desde regiões abjetas.

Em alinhamento explicativo ao comentário elaborado por Rui, bem como em consonância com o posicionamento interacional por ele mobilizado, mediante referências e predicações, por ele estabelecidas, o comentário de Ana intenta dar as razões pelas quais as mulheres negras seriam preteridas no contexto das relações afetivas, conforme sustenta o 
comentador anterior. Então, ele aciona uma sequência de pistas indexicais na forma de referências, como em "padrão de BELEZA, romantismo e atração", e as predica com a expressão "é brancocêntrico". Nesse ponto, é possível ver o potencial de reflexividade social (GIDDENS, 1991) desempenhado pelo comentário da participante, uma vez que aciona conhecimentos advindos do pensamento acadêmico (branquitude e brancocentrismo são conceitos desenvolvidos nas ciências sociais para se pensar as relações raciais) para refletir sobre a prática social da vida cotidiana na qual está inserida. Ainda nesse contexto, tal reflexividade age na direção de elaborar contranarrativas que desnaturalizam um dos eixos organizadores centrais do poder na Modernidade, os processos coloniais e o racismo advindo deles.

Tais pistas indexicais mobilizam um posicionamento interacional que se coloca como favorável tanto ao posicionamento levantado na matéria postada por Geledés quanto ao comentário anterior, justamente por instaurarem um modo de reflexividade que, conforme foi argumentado, desnaturaliza dispositivos coloniais diretamente ligados ao campo afetivo-relacional, geralmente tomados como essencializados, naturais, dados internos aos sujeitos e, por isso, imunes à cultura, às ideologias e, consequentemente, à crítica, a exemplo das referências "romantismo" (aqui entendido como concernente aos envolvimentos afetivos dos sujeitos) e "atração" (relativo a desejo sexual ou investimento libidinal). Ainda nessas referências, a comentadora alude ao "padrão de BELEZA" e predica todos os elementos referenciados como "brancocêntricos". Dessa forma, sustenta que os quadros normativos de poder nos quais as mulheres negras são significadas como preteríveis (em face do "romantismo", da "atração" e dos "padrões de BELEZA") são todos produzidos a partir de uma lógica colonial que elabora, projeta e hierarquiza as performances de raça, posicionando o elemento branco como não marcado, superior, padrão a ser seguido, inclusive em termos de estilizações estético-corporais, ou seja, de beleza.

Ainda nessa direção, ao elaborar um posicionamento interacional desnaturalizante das lógicas que informam as hierarquias afetivo-relacionais baseadas na intersecção gênero/raça, a participante Ana deixa pistas indexicais que apontam para outro processo social implicado nessa dinâmica, a branquitude. Ao avaliar o brancocentrismo como criado e sustentado pela branquitude, assevera o posicionamento assumido, enfatizando que as performances de raça associadas ao elemento não marcado do 
binômio colonial, o branco, são tomadas como índices de normalização de performances de raças outras, a exemplo daquelas relativas à negritude. Desse modo, é pelo imperativo de que corpos negros devem embranquecerse, desde suas estilizações corporais até suas práticas culturais, como único meio de deslocar-se de sua condição de inferioridade, que se sustentam e se replicam as lógicas brancocêntricas de romantismo, de atração e de padrões de BELEZA.

FIGURA 4 - Comentário sobre o texto "Você amaria uma mulher negra?" no Facebook

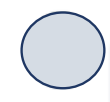

Liz primeiro as negras tem que provar que sao boas na, cama, na cozinha etc... depois quase nunca sao assumidas, como mulher,amante, ou maes..."os inumeros contos de Fadas ja provam" elas quase nunca sao amadas.

\section{Curtir Responder $5 \mathrm{~d}$}

Fonte: Facebook (2018).

Na Figura 4, o comentário elaborado por Liz mobiliza um posicionamento interacional que, em primeira instância, estabelece como premissa a desigualdade interseccional entre mulheres brancas e mulheres negras, uma vez que recorre a uma referência que projeta diferenças de raça e gênero num mesmo signo, as negras. Nesse caso, a esse referente é atribuída certa capacidade de agência que malogra qualquer possibilidade de considerá-lo como propalador de uma autonomia da mulher negra, uma vez que semanticamente está engajado numa tarefa que subordina essa ação a outrem, ao homem, à sociedade, os quais funcionam como não ditos racistas e sexistas altamente significantes nos modos de constituição semióticodiscursiva de seu posicionamento.

As pistas indexicais que predicam essa referência generificada e racializada, as negras, como aquelas "que têm que provar que são boas na cama, na cozinha etc" produzem sentidos que indexam, de modo crítico, discursos nos quais a condição subalterna de que gozam as mulheres negras, dados os efeitos dos marcadores sociais projetados sobre seus corpos, além de previamente assumida, em outras palavras, naturalizada, só pode ser eventualmente superada em face de seu atendimento a uma determinada performance esperada da mulher negra, calcada em essencialismos racistas 
e estereotipados. Sob a égide dessa performance, mulheres negras são produzidas enquanto parceiras sexuais ideais, pois todas seriam dotadas de sensualidade e de atributos físicos hipererotizados, bem como de habilidades domésticas e culinárias natas, cujas existências estão todas consagradas à satisfação do homem branco. Tais sentidos estão em circulação nos efeitos de discursos coloniais que produziram modos de inteligibilidade dos corpos de mulheres negras, subordinando-os a "imagens de controle" (BAIRROS, 1995) que ensejam objetificar e limitar suas possibilidades de subjetivação.

Nessa mesma tarefa crítica, o comentário destacado na Figura 4 predica as negras como aquelas que "quase nunca são assumidas como mulher, amante, ou mães". Tais pistas indexicais reiteram um posicionamento interacional calcado na crítica às violências racistas exercidas contra mulheres negras no contexto das relações afetivas, em consonância com o posicionamento sustentado pela postagem de Geledés. Desta feita, ao serem predicadas desse modo, apesar de ainda denunciarem reivindicações que circunscrevem o corpo da mulher negra em esferas privadas da vida social, indexicalizam discursos que apontam para outra faceta dessa perspectiva da subalternidade: a invisibilidade compulsória no campo afetivo-relacional produzida quase sempre por parceiros, homens brancos, que temem ver recair sobre si o estigma destinado à sua companheira, uma mulher negra, em razão de suas performances de raça e de gênero.

É no sentido dessa condição de invisibilidade - que faz feministas negras como Kilomba (2012) afirmarem que mulheres negras habitam um vazio às margens da sobreposição de raça e de gênero, como que um vácuo de apagamento e contradição - que Liz finaliza seu comentário aludindo a produtos culturais em circulação, especificamente às narrações infantis, recontextualizando a expressão "os inúmeros contos de fada já provam' elas quase nunca são amadas”. Assim, o posicionamento interacional mobilizado pela participante evidencia outra faceta da lógica brancocêntrica já predicada pela participante Ana, na Figura 3: sua estratégia de invisibilização das mulheres negras nos produtos culturais ou sua subrepresentação, ou seja, demarcando-as nesses lugares simbólicos (e políticos) de subalternidade, objetificação, sofrimento e infelicidade.

Em razão desse processo de as mulheres negras serem significadas como esse outro invisibilizado, desde a posição e o olhar do sujeito tomado como universal, "o homem branco", é que se justifica a reivindicação de mulheres negras em se autodefinirem, ou seja, de produzirem discursos 
sobre si mesmas a partir de uma análise centrada nas posições corporais, epistemológicas e políticas de mulheres negras em movimento. Razões essas que, segundo Collins (2016, p. 105), estão centradas na tarefa de "definir e valorizar a consciência do próprio ponto de vista definido frente a imagens que promovem sua autodefinição sob a forma de 'outro objetificado', efeito da 'desumanização essencial dos sistemas de dominação".

FIGURA 5 - Comentário sobre o texto "Você amaria uma mulher negra?" no Facebook

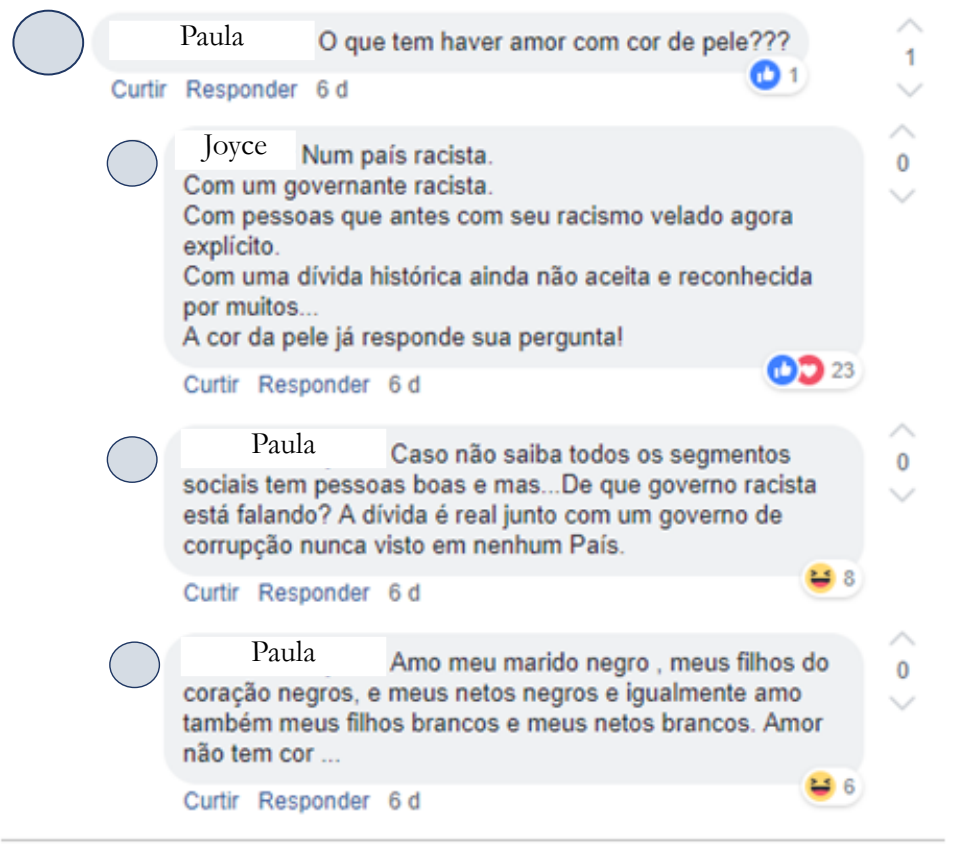

Fonte: Facebook (2018).

$\mathrm{Na}$ troca interacional registrada pela Figura 5, os comentários mobilizam posicionamentos interacionais distintos e que operam por meio de ordenamentos diversos. De um lado, tem-se a comentadora Paula, que elabora um posicionamento desfavorável em relação àquele veiculado no conteúdo compartilhado pela página de ativismo digital, e, do outro, a participante Joice, que veicula um posicionamento que entra em desalinhamento com aquele sustentado por Paula, alinhando-se, então, ao conteúdo replicado pela página. 
Nesse sentido, levando-se em consideração a resposta elaborada por Joice à pergunta "O que tem haver amor com cor da pele???”, presente no comentário de Paula à matéria, nota-se que o posicionamento de Paula foi interpretado como um tipo de posicionamento interacional que visava a questionar não apenas a validade do tópico discursivo inaugurado, mas a pôr sob suspeita a legitimidade da demanda social levantada pelo conteúdo ativista compartilhado, recorrendo, para tanto, ao expediente discursivo da ironia. Desse modo, a contribuição interacional inicial é tomada como um não reconhecimento dos sujeitos representados nas discussões ali pontuadas, as quais seriam irrelevantes, uma vez que, segundo o(a) comentador(a), não haveria nexo ou implicação qualquer que fosse entre amor e raça (cor da pele), entre relações afetivas e políticas. Essa negação significa, em certo sentido, um apagamento naturalizador das diferenças, das hierarquias e dos conflitos implicados na produção de performances identitárias situadas, negando, assim, a política como uma ação cotidiana. Tais sentidos projetam um modo de agência que opera por meio da interdição de demandas ativistas do feminismo negro.

No que tange às dinâmicas interacionais, a contribuição interacional de Paula posicionou a si mesma em face do discurso ativista do feminismo negro, situando-se num lugar não marcado em termos de raça, ou seja, num lugar social privilegiado em que efetivamente seu corpo não é afetado pelas investidas subalternizantes das relações de poder em questão. Assim, não pode sentir a relação (política) entre o que ela referencia como "amor" e "cor da pele", em outras palavras, entre a projeção de marcadores de gênero e de raça, especialmente em sua faceta mais violenta, a conjunção entre racismo e sexismo. Desse modo, pode-se dizer que esta participante mobiliza os recursos semióticos socialmente disponíveis com vistas a reivindicar para si um posicionamento identitário desejado (DAVIES; HARRÉ, 1990, p. 6), o qual, uma vez se situando discursivamente como não racializado, se percebe autorizado a racializar o outro.

Em consequência desse modo de posicionar a si mesma, o discurso da participante em tela interpela os sujeitos políticos dessa prática ativista em questão - mulheres negras - a ocuparem um lugar de invisibilidade de suas demandas e de deslegitimação de suas sensibilidades políticas, projetadas na prática semiótica em disputa. Por se tratar de uma postagem aberta a uma multiplicidade de leitores(as) e suas contribuições/interpretações, característica própria de espaços de ativismo digital, o comentário de 
Joice, posicionando a si mesma no lugar do sujeito político do feminismo negro, a mulher negra, sinaliza que o posicionamento de invisibilidade e deslegitimação a ela imputado pela contribuição interacional de Paula foi rejeitado.

Em resposta a tal contribuição, a segunda comentadora elabora seu posicionamento interacional listando uma gama de pistas indexicais que referenciam e predicam uma série de objetos do mundo com vistas a caracterizá-los (WORTHAM, 2001), a significá-los desde o posicionamento feminista negro projetado: "num país racista, um governante racista, pessoas que antes com seu racismo velado, agora explícito". Nesse sentido, as pistas indexicais produzem sentidos que denunciam as tramas do racismo estrutural e institucional historicamente enraizadas na sociedade brasileira e sua trajetória escravagista e colonial, as quais são capazes, inclusive, de desvelar os discursos atualizados em posicionamentos como os sustentados pela participante Paula, de completa naturalização e incapacidade de reconhecimento das assimetrias de raça - e de gênero implicadas nas relações intersubjetivas, em geral, e nas relações afetivas, em particular.

Conforme os dois comentários elaborados por Paula, como réplicas ao posicionamento ativista e antirracista sustentado por Joice, é possível perceber que esta viu a si mesma interpelada pela sua interactante a ocupar um posicionamento alinhado ao racismo. A fim de deslegitimar tal estratégia de posicionamento, ela, Joice, recorre novamente à ironia como recurso discursivo com vistas a invalidar o tópico em torno do qual dialogam/ disputam (o racismo), agora instaurando generalizações que visam a negar diferenças raciais e seus efeitos na vida social ("Caso não saiba todos os segmentos sociais tem pessoas boas e mas..."), bem como a perguntas retóricas que agem no mesmo sentido ("De que governo racista você está falando?"). Para completar as estratégias de fuga/rejeição do posicionamento interacional racista que lhe é imputado por Joice, Paula desloca o tópico discursivo para "corrupção do governo", aludindo a ser essa a "dívida histórica" "“A dívida é real junto com um governo nunca visto em nenhum País"), produzindo, assim, uma pista indexical de citação indireta.

Ao cabo das manobras interacionais de refutação do posicionamento racista que lhe fora imputado, Paula, em novo comentário, afirma para si um posicionamento interacional não racista, buscando estratégias que 
afirmem sua tese inicial de que não há qualquer relação de implicação entre afeto e variáveis de natureza política, a exemplo daquelas da ordem das performances de raça. Assim, as pistas indexicais de referência e predicação por meio das quais ela enumera a abrangência de seu afeto supostamente não racista, curiosamente restrito à sua esfera familiar, indexicalizam discursos cristalizados socialmente no Brasil que dão conta de uma suposta miscigenação pacífica, base do mito da democracia racial (NASCIMENTO, 2016) e, ainda, do imaginário de um Brasil como país plural, aberto à diversidade, lugar de harmoniosa convivência entre as diferenças.

Uma observação mais geral da forma como posicionamentos interacionais e pistas indexicais se articulam para produzir performances identitárias raciais e de gênero, mediante uma visada interseccional, no material de análise deste artigo, nos abre possibilidades interpretativas para a compreensão da maneira como recursos semióticos de caráter linguístico dentre outros - projetam/negociam/disputam sentidos sociais mais amplos. Conforme discute Fabrício (2013, p. 115) a respeito dos modos de agência situada de sujeitos em práticas comunicativas, "os diversos repertórios indexicais que eles trazem para um único encontro internacional indicam os limites e a vulnerabilidade dos processos de negociação do sentido", conotando, assim, tanto as diferenças entre os repertórios de que lançam mão os sujeitos em suas performances quanto o caráter multidimensional (situado e global) dos processos de significação em curso nas diferentes práticas sociais semioticamente constituídas.

\section{Considerações finais}

Grosso modo, as incursões teóricas e as práticas analíticas empreendidas neste artigo permitem argumentar em favor de algumas constatações que, embora sejam, em alguns casos, já correntes em outros trabalhos desenvolvidos no campo, carecem ainda de maior aprofundamento, dada a necessidade de desconstruir a longa tradição essencialista e representacionalista na interpretação dos fenômenos de linguagem e suas consequências políticas, a saber:

(1) o intenso potencial de reflexividade social de práticas de ativismo digital, especialmente no que tange à contestação de valores que direcionam as práticas sociais segundo uma tradição modernista, a exemplo de ideologias coloniais, racistas e sexistas, produzindo, assim, narrativas sociais alternativas, 
baseadas em práticas contínuas de reflexão dos sujeitos acerca das atividades públicas nas quais estão engajados;

(2) a possibilidade analítica, para a investigação das relações entre discursos e identidades na Linguística Aplicada, desde uma visada não essencialista, do diálogo entre perspectivas performativas e semióticas da questão identitária e a proposta dos posicionamentos interacionais. Isso porque tal articulação permite justamente considerar processos de emergência de significados históricos, sociais e culturais de gênero e de raça em dinâmicas de elaboração interacionais microlocalizadas, a exemplo das interações em mídias digitais como as aqui discutidas; e

(3) a produtividade de uma perspectiva interseccional acerca da elaboração de performances identitárias, especialmente por permitir perspectivar diferentes modos de interpelação de diferentes eixos de poder, especialmente no que tange à projeção cruzada de marcas de diferenças coloniais subalternizantes na produção de corpos e subjetividades, a exemplo daquelas que intersectam diferenças de gênero e de raça (dentre outras) na produção discursiva da condição abjeta de mulheres negras.

Em face dos pontos levantados, quer para uma ação política mais eficaz dos movimentos sociais, quer para a elaboração de uma analítica do poder e da resistência semioticamente encarnada em práticas de linguagem, a exemplo do que tem sido feito em linguística aplicada, a promoção do diálogo entre perspectivas performativas, decoloniais e interseccionais parece cada vez mais importante. Nesse aspecto reside a complexidade da tarefa de se pensar e se intervir sobre situações de exclusão estruturais, complexas e multifacetadas, as quais tanto se atualizam quanto são rasuradas nas diferentes semioses e práticas discursivas que constituem a vida social contemporânea.

Para tanto, é relevante a reinvenção de práticas analíticas e de fazeres metodológicos capazes de dar conta, em seu desenho, de processos identitários de diferentes ordens, pautados pela lógica de um conhecimento sempre contingente (MOITA LOPES, 2009), reconhecendo, assim, a prática de pesquisa, tanto quanto seus "objetos", enquanto fenômenos situados. Esses desafios ganham particular relevo especialmente em tempos de recrudescimento de narrativas essencialistas e fixistas sobre as identidades sociais, a exemplo do que tem vivido a sociedade brasileira desde sua guinada política à extrema-direita, em 2018. Nesse cenário, se faz imprescindível uma produção do conhecimento engajada na contestação de violências e desigualdades baseadas em gênero, raça e classe social. 


\section{Referências}

AGHA, A. Language and Social Relations. Cambridge: Cambridge University Press, 2007.

AUSTIN, J. How to Do Things with Words. Cambridge: Harvard University Press, 1975. DOI: https://doi.org/10.1093/acprof:oso/9780198245537.001.0001

BAIRROS, L. Nossos feminismos revisitados. Estudos Feministas, Florianópolis, v. 3, n. 2, p. 458-463, 1995.

BERTUCCI, R. A.; NUNES, P. A. Interação em rede social: das reações às características do gênero comentário. Dominios de Linguagem, Uberlândia, v. 11, n. 2, p. 313-338, 2017. DOI: https://doi.org/10.14393/DL29-v11n2a2017-3

BLOMMAERT, J. Discourse. Cambridge: Cambridge University Press, 2005.

BORBA, R. A linguagem importa? Sobre performance, performatividade e peregrinações conceituais. Cadernos Pagu, Campinas, n. 43, p. 441-474, 2014. DOI : https://doi.org/10.1590/0104-8333201400430441

BRAGA, D. B. Tecnologia e participação social no processo de produção e consumo de bens culturais: novas possibilidades trazidas pelas práticas letradas digitais mediadas pela internet. Trabalhos em Linguística Aplicada, Campinas, v. 49, n. 2, p. 373-391, 2010. DOI: https://doi.org/10.1590/S0103-18132010000200005

BRAGA, D. B. Tecnologias digitais da informação e da comunicação e participação social. São Paulo: Cortez, 2015.

BUCHOLTZ, M.; HALL, K. Identity and Interaction: A Sociocultural Linguistic Approach. Discourse Studies, Thousand Oaks, v. 7, n. 4-5, p. 585-614, 2005. DOI: https://doi.org/10.1177/1461445605054407

BUTLER, J. Bodies that Matter: On the Discursive Limits of "Sex". New York: Routledge, 1993.

BUTLER, J. Problemas de gênero: feminismo e subversão da identidade. Tradução de Renato Aguiar. Rio de Janeiro: Civilização Brasileira, 2017.

CAMERON, D. Performing Gender Identity: Young Men's Talk and the Construction of Heterosexual Masculinity. In: JOHNSON, S.; MEINHOF, U. (ed.). Language and Masculinity. London: Blackwell, 1997. p. 47-64.

CARNEIRO, S. Enegrecer o feminismo: a situação da mulher negra na América Latina a partir de uma perspectiva de gênero. In: ASHOKA EMPREENDEDORES SOCIAIS; TAKANO CIDADANIA (org.). Racismos contemporâneos. Rio de Janeiro: Takano, 2003. 
COLLINS, P. H. Aprendendo com a outsider within: a significação sociológica do pensamento feminista negro. Sociedade e Estado, Brasília, DF, v. 31, n. 1, p. 99-127, 2016. DOI: https://doi.org/10.1590/S0102-69922016000100006

CRENSHAW, K. Demarginalizing the Intersection of Race and Sex: A Black Feminist Critique of Antidiscrimation Doctrine, Feminist Theory and Antiracist Politics. University of Chicago Legal Forum, Chicago, n. 1, p. 138-167, 1989.

CRENSHAW, K. Documento para o encontro de especialistas em aspectos da discriminação racial relativos ao gênero. Revista Estudos Feministas, Florianópolis, v. 10, n. 1, p. 171-188, 2002. DOI: https://doi.org/10.1590/S0104-026X2002000100011 DAVIES, B.; HARRÉ, R. Positioning: the discursive production of selves. Journal for the Theory of Social Behaviour, Hoboken, v. 20, n. 1, p. 43-63, 1990. DOI: https:// doi.org/10.1111/j.1468-5914.1990.tb00174.x

DERRIDA, J. Limited inc. Tradução de Constança Marcondes Cesar. Campinas: Papirus, 1991.

FACEBOOK. Página do Geledés. Postagem Você amaria uma mulher negra?" de 20 dez. 2018. Disponível em: https://www.facebook.com/geledes/ posts/10155682000206816. Acesso em: 10 jan. 2019.

FABRÍCIO, B. F. A “outridade lusófona” em tempos de globalização: identidade cultural como potencial semiótico. In: MOITA LOPES, L. P. (org.) Português no século XXI: ideologias linguísticas. São Paulo: Parábola, 2013. p. 144-168.

FABRÍCIO, B. F. Linguística aplicada e visão de linguagem: por uma INdisciplinaridade radical. Revista Brasileira de Linguística Aplicada, Belo Horizonte, v. 17, n. 4, p. 599-617, 2017. DOI: https://doi.org/10.1590/1984-6398201711426

FANON, F. Pele negra, máscaras brancas. Salvador: Edufba, 2008. DOI: https:// doi.org/10.7476/9788523212148

FERNANDES, F. A integração do negro na sociedade de classes: ensaio de interpretação sociológica. Prefácio de Antonio Sérgio Alfredo Guimarães. São Paulo: Biblioteca Azul; Globo, 2014. v. II.

GARCIA, C. C. Os novos feminismos e os desafios para o século 21. Revista Cult, n. 199, p. 52-55, 2015.

GELEDÉS: missão institucional. Geledés, São Paulo, 10 abr. 2016. Disponível em: https://bit.ly/3muUULv. Acesso em: 10 jan. 2018.

GIDDENS, A. As consequências da modernidade. São Paulo: Unesp, 1991.

GILROY, P. O Atlântico negro: modernidade e dupla consciência. Tradução de Cid Knipel Moreira. 2. ed. São Paulo: Editora 34, 2012. 
GONZALEZ, C.; MOITA LOPES, L. P. Posicionamentos interacionais mobilizados por Tudo sobre minha mãe na rede social Filmow. DELTA, São Paulo, v. 31, n. 2, p. 473-503, 2015. DOI: https://doi.org/10.1590/0102445011081768832268

GUIMARÃES, T. F.; MOITA LOPES, L. P. Entextualizações estratégicas: performances sensualizadas de raça em práticas discursivas na Web. 2.0. Linguagem em Discurso, Tubarão, v. 16, n. 2, p. 289-307, 2016. DOI: https://doi. org/10.1590/1982-4017-160206-3515

GUIMARÃES, T. F.; MOITA LOPES, L. P. Trajetória de um texto viral em diferentes eventos comunicativos: entextualização, indexicalidade, performances identitárias e etnografia. Alfa, São Paulo, n. 61, v. 1, p. 11-33, 2017. DOI: https:// doi.org/10.1590/1981-5794-1704-1

HARAWAY, D. Manifesto ciborgue: ciência, tecnologia e feminismo-socialista no final do século XX. In: TADEU, T. (org.). Antropologia do ciborgue: as vertigens do pós-humano. Belo Horizonte: Autêntica Editora, 2009.

HINE, C. Virtual Ethnography. London: Sage Publications, 2002.

IPEA. Mulheres e trabalho: breve análise do período 2004-2014. 2016. Disponível em: https://www.ipea.gov.br/portal/index.php?option=com_ content\&view $=$ article\&id $=27317$. Acesso em: 9 jan. 2019.

KILOMBA, G. Plantation Memories: Episodes of Everyday Racism. Munster: Unrast Verlag, 2012. Disponível em: https://goo.gl/w3ZbQh. Acesso em: 10 jan. 2019.

MAIA, J. O. Letramentos de sobrevivência em redes digitais: caminhos possíveis na luta por direitos humanos. Trabalhos em Linguistica Aplicada, Campinas, n. 57, n. 2, p. 954-974, 2018. DOI: https://doi.org/10.1590/010318138651932366491

MARTINEZ, F. Feminismos em movimentos no ciberespaço. Cadernos Pagu, Campinas, n. 56, p. 1-34. 2019. DOI: https://doi.org/10.1590/1809444920190 0560012

MBEMBE, A. Necropolitica. São Paulo: N-1 Edições, 2018.

MELO, G.; MOITA LOPES, L. P. "Você é uma morena muito bonita”: a trajetória textual de um elogio que fere. Trabalhos em Linguística Aplicada, Campinas, n. 54, n. 1, p. 53-78, 2015. DOI: https://doi.org/10.1590/0103-18134345161352

MIGNOLO, W. Colonialidade: o lado mais escuro da modernidade. Revista Brasileira de Ciências Sociais, São Paulo, v. 32, n. 94, p. 1-18, 2017. DOI: https://doi. org/10.17666/329402/2017 
MOITA LOPES, L. P. (org.). Por uma linguística aplicada indisciplinar. São Paulo: Parábola Editorial, 2006.

MOITA LOPES, L. P. Linguística aplicada como lugar de construir verdades contingentes: sexualidades, ética e política. Gragoatá, Niterói, v. 14, n. 27, p. 33-50, 2009. DOI: https://doi.org/10.5533/1413-9073-20092703

MOITA LOPES, L. P. Os novos letramentos digitais como lugares de construção de ativismo político sobre sexualidade e gênero. Trabalhos em Linguística Aplicada, Campinas, v. 49, n. 2, p. 393-417, 2010. DOI: https://doi.org/10.1590/S010318132010000200006

MUNIZ, K. Ainda sobre a possibilidade de uma linguística "crítica": performatividade, política e identificação racial no Brasil. DELTA, São Paulo, v. 23, n. 3, p. 767-786, 2016. DOI: https://doi.org/10.1590/0102-445063437589564459

NASCIMENTO, A. O genocídio do negro brasileiro. São Paulo: Perspectiva, 2016.

NATANSOHN, G. (org.). Internet em código feminino: teorias e práticas. Buenos Aires: La Crujía, 2013.

PINTO, J. Performatividade radical: ato de fala ou ato de corpo. Gênero, Niterói, v. 3, n. 1, p. 101-110, 2002. DOI: https://doi.org/10.22409/rg.v3i1.260

PINTO, J. Conexões teóricas entre performatividade, corpo e identidades. DELTA, São Paulo, v. 23, n. 1, p. 1-26, 2007. DOI: https://doi.org/10.1590/ S0102-44502007000100001

PINTO, J. De diferenças e hierarquias no quadro Adelaide às análises situadas e críticas na linguística aplicada. DELTA, São Paulo, v. 31, n. especial, p. 199-221, 2015. DOI: https://doi.org/10.1590/0102-445000598096269281

PINTO, J.; AMARAL, D. Corpos em trânsito e trajetórias textuais. Revista da Anpoll, Florianópolis, v. 1, n. 40, p. 151-164, 2016. DOI: https://doi.org/10.18309/anp. v1i40.1024

PUAR, J. Prefiro ser um ciborgue a ser uma deusa: interseccionalidade, agenciamento e política afetiva. Meritum, Belo Horizonte, v. 8, n. 2, p. 343-370, 2013.

QUIJANO, A. Colonialidade do saber: eurocentrismo e ciências sociais. In: LANDER, E. (org.). A colonialidade do saber: eurocentrismo e ciências sociais: perspectivas latino-americanas. Buenos Aires: Clacso, 2005. p. 227-278.

RAMPTON, B. Continuidade e mudança nas visões de sociedade em Linguística Aplicada. In: MOITA LOPES, L. P. (org.). Por uma linguística aplicada indisciplinar. São Paulo: Parábola Editorial, 2006. p. 108-128. 
SCHERER-WARREN, I. Das mobilizações às redes de movimentos sociais. Sociedade e Estado, Brasília, DF, v. 21, n. 1, p. 109-130, 2006. DOI: https://doi. org/10.1590/S0102-69922006000100007

SCHUCMAN, L. V. Entre o "encardido", o "branco" e o "branquíssimo": raça, hierarquia e poder na construção da branquitude paulistana. 2012. Tese (Doutorado em Psicologia) - Instituto de Psicologia, Universidade de São Paulo, São Paulo, 2012.

SILVA, D. C. P. Quando dižer é violentar: violência linguística e transfobia em comentários online. Devires: Salvador, 2019.

SILVERSTEIN, M. Indexical Order and the Dialectics of Sociolinguistic Life. Language \& Communication, [S.l.], n. 23, p. 193-229, 2003. DOI: https://doi. org/10.1016/S0271-5309(03)00013-2

UGARTE, D. O poder das redes: manual ilustrado para pessoas, organizações e empresas chamadas a praticar o ciberativismo. Porto Alegre: EDIPUCRS, 2008.

WORTHAM, S. Narratives in Action. New York: Teacher College Press, 2001.

Data de submissão: 29/01/2019. Data de aprovação: 04/09/2020. 